\title{
Anna Lis-Zaldivar
}

Akademia im. Jakuba z Paradyża w Gorzowie Wielkopolskim

\section{Uszkodzenie słuchu jako problem społeczny}

W każdym okresie życia może nastąpić uszkodzenie słuchu, począwszy od okresu prenatalnego aż do późnej starości. Etiologia wad słuchu jest zróżnicowana. Obciążenie genetyczne, zespoły wad wrodzonych, zatrucia prenatalne, uszkodzenia okołoporodowe, zachorowania, to ważne przyczyny uszkodzeń słuchu małych dzieci. $W$ wieku dojrzałym obniżenie słuchu jest spowodowane degeneracją komórek słuchowych oraz chorobami ogólnoustrojowymi. Dzięki przesiewowym badaniom słuchu noworodków zwiększa się wykrywalność wad powstałych w tym okresie życia. Jednakże wiek przedszkolny, szkolny, po 40. i 60. roku życia są okresami szczególnie podatnymi na obniżenie ostrości słyszenia. Dlatego też screening słuchowy powinien być wykonywany również $w$ tych etapach życia. Wczesne podejrzenie niedosłuchu nie gwarantuje podjęcia racjonalnych działań ukierunkowanych na diagnozę i rehabilitację. Brak skutecznego systemu kontrolnego generuje opóźnienia w tym zakresie, co skutecznie obniża rezultaty rehabilitacji. Starzenie się społeczeństwa implikuje wzrost liczby osób z wadami słuchu, wiąże się to obniżeniem jakości życia w zakresie kontaktów społecznych i poczucia wartości. Utrata słuchu nadal dla części społeczeństwa jest problemem wstydliwym, który należy ukrywać nawet przed najbliższymi osobami.

Słowa kluczowe: wada słuchu, badania słuchu, badania przesiewowe, słuch, problem społeczny

\section{Hearing impairment as social problem}

The hearing loss can occur at any stage of life - from prenatal to late old age. Etiology of hearing defects is varied: genetic load, congenital malformations, prenatal intoxications, perinatal injuries. The important causes of hearing impairment in young children could be diseases. In adulthood, hearing loss is caused by hearing cell degeneration and systemic diseases. Newborn hearing screening enables early detection of defects occurred at this stage of life. However hearing impairment could also be detectable at preschool and school age, as well as at over forty-year-olds or sixty -year -olds. Therefore, auditory screening should also be applied at these stages of life. The early detection of hearing loss does not however guarantee a rational approach to diagnosis and rehabilitation. The lack of effective control system causes undue delays, meaningfully reducing the results of rehabilitation. Due to the aging of the population in the developed world, hearing impairment is a growing problem that has been reported to reduce quality of life, particularly reducing one's social activity and relations as well as the sense of value. Furthermore, hearing loss still remains a shameful and embarrassing problem in a society which eventually should be hidden even within the immediate family.

Keywords: hearing loss (hearing impairment), illness, social problem, senior, hearing screening (hearing screening) 


\section{Wprowadzenie}

W każdym okresie życia może nastąpić uszkodzenie słuchu, począwszy od okresu prenatalnego do późnej starości. Etiologia wad słuchu jest zróżnicowana. Obciążenie genetyczne, zespoły wad wrodzonych, zatrucia prenatalne, uszkodzenia okołoporodowe, zachorowania, to ważne przyczyny uszkodzeń słuchu małych dzieci. W wieku dojrzałym obniżenie słuchu jest spowodowane przede wszystkim degeneracją komórek słuchowych oraz chorobami ogólnoustrojowymi. Przesiewowe badania słuchu pozwalają zdiagnozować stan drogi słuchowej noworodków i przyspieszyć zainicjowanie terapii. Jednakże również wiek przedszkolny, szkolny, po 40. i 60. roku życia są okresami szczególnie podatnymi na obniżenie ostrości słyszenia. Dlatego też screening słuchowy powinien być wykonywany również $\mathrm{w}$ kolejnych etapach życia. Praktyka pokazuje, że wczesne określenie niedosłuchu nie gwarantuje podjęcia racjonalnych działań ukierunkowanych na diagnozę i rehabilitację. Brak skutecznego systemu kontrolnego generuje opóźnienia w tym zakresie, co skutecznie obniża rezultaty rehabilitacji. Starzenie się społeczeństwa implikuje wzrost liczby osób z wadami słuchu, wiąże się to obniżeniem jakości życia w zakresie kontaktów społecznych i poczucia wartości. Obniżenie ostrości słyszenia nadal dla części społeczeństwa jest problemem wstydliwym.

\section{Znaczenie słuchu}

Narząd słuchu jest jednym z najważniejszych zmysłów człowieka. Pozwala rozszerzyć przestrzeń poznawczą do obszarów, które nie mogą być zbadane innymi zmysłami, np. wzrokiem, dotykiem, zapachem. Dzięki niemu możliwe jest permanentne identyfikowanie, rozpoznawanie, analizowanie i weryfikacja najbliższego, jak i dalszego środowiska. Wyzwala się poczucie bezpieczeństwa lub jego brak. Bodźce słuchowe w szczególny sposób przygotowują do przewidywania nadchodzących zmian, wydarzeń, np. dźwięk otwieranych drzwi sugeruje przybycie kogoś lub wyjście z pomieszczenia. Specyfika odgłosów (barwa, intensywność itp.) inspiruje zastosowanie odpowiednich zabiegów, np. rozłoszczony głos w telefonie mobilizuje do rozmowy wyciszonej lub całkiem odwrotnie pobudzonej. Impulsy dźwiękowe aktywizują lub hamują działalność człowieka. Bezpośrednio wpływają na doznania estetyczne, kształtując wrażliwość akustyczną. Słuch warunkuje formułowanie sprawności językowych zarówno w mowie biernej (zrozumienie), jak i czynnej (mówienie) oraz kompetencje poznawcze. Co więcej, mowa wnosi bezpośredni i twórczy wkład w proces rozwiązywania problemów, 
czyniąc go bardziej przemyślanym i planowym. Komunikaty werbalne pobudzają i rozwijają mowę wewnętrzną, która przeobraża procesy intelektualne i wznosi je na wyższy poziom. ,....mowa zwielokrotnia możliwości myśli w zakresie szerokości i szybkości..." [Piaget, Inhelder 1999, s. 66]. Ponadto ustna komunikacja wpływa na uspołecznienie i kształtowanie osobowości młodego człowieka.

\section{Rozwój i przyczyny uszkodzenia słuchu}

Narząd słuchu rozwija się od 4 tygodnia życia płodowego [Eliot 2003, s. 319]. Jednak nawet po dalszych ośmiu miesiącach dojrzewania nie jest $\mathrm{w}$ pełni sformułowany. „Słuch wyostrza się w miarę stopniowej mielinizacji i doskonalenia się synaps najpierw w pniu mózgu, a później w biorących udział w słyszeniu struk- turach korowych." [Eliot 2013, s. 332]. Wymaga czasu i empirii. Wrażliwość na pełny zakres częstotliwości tonalnej, lokalizacji dźwięku formułuje się w pierwszym półroczu życia. [Eliot 2013, s. 333]. Jednakże potrzeba kilka lat wypełnionych ćwiczeniami, aby dziecko $\mathrm{w}$ pełni nabyło umiejętność $\mathrm{w}$ zakresie analizy i syntezy słuchowej dźwięków mowy.

Koniecznym faktorem prawidłowego wykształcenia się zmysłu słuchu są warunki biologiczne organizmu oraz brak patogennych czynników środowiska. Doświadczenie oraz praktykowanie działań zwrotnych (bodziec - reakcja, np. dzwonek - odbieranie telefonu).

W każdym okresie życia, od poczęcia aż do późnej starości, mogą wystąpić wady słuchu o zróżnicowanej etiologii. Jedną z nich są uwarunkowania genetyczne. Genetyk L. Korniszewski [2013] stwierdza, że w Polsce około 3\% mieszkańców jest nosicielami jednej kopii zmutowanego genu GJB2, który może prowadzić do uszkodzenia słuchu. Prawdopodobieństwo wystąpienia defektu słuchu u dziecka, gdy dwoje rodziców posiada kopię genu GJB2, wynosi 25\% [Korniszewski 2013]. Około 20\% niedosłuchów powstaje poprzez dziedziczenie dominującego zmutowanego genu GJB2 [Korniszewski 2013]. W tym przypadku problemy w słyszeniu ujawniają się około $30-40$ r.ż., a sam niedosłuch przebiega w łagodniejszej formie niż w sytuacji recesywnego dziedziczenia.

$30 \%$ dzieci urodzonych z wadą słuchu posiada zespoły wad wrodzonych [Audiology News, 4/2016, s. 10], np. Zespół Waardenburga. Objawiający się siwym pasmem włosów - biały lok, zmianami w obrębie tęczówki, przebarwieniami na skórze klatki piersiowej, dysfunkcją w uchu wewnętrznym. Zespół Ushera łączący głęboki niedosłuch z zwyrodnieniem barwnikowym siatkówki oka. Zespół Sticklera odznacza się postępującym odbiorczym ubytkiem słuchu, płaską twarzą, krótkowzrocznością, odklejaniem siatkówki, rozszczepem podniebienia, 
zmianami zwyrodnieniowymi stawów. Również zaburzenia w pracy tarczycy mogą stanowić źródło etiologii utraty słuchu, np. Zespół Pendreda cechuje się niedoczynnością tarczycy oraz wadami ucha wewnętrznego powodującymi głęboki niedosłuch. Zapalenie tarczycy Hoshimoto wpływa na obniżenie ostrości słyszenia, z częstym współwystępowaniem szumów usznych [Audiology News, 2016, s. 9-10].

W okresie okołoporodowym i poporodowym czynnikami obciążającymi słuch są m.in.: wcześniactwo, niedotlenienie okołoporodowe, hiperbilirubinemia, przyjmowanie leków ototoksycznych, zapalenie opon mózgowo-rdzeniowych; we wczesnym dzieciństwie: choroby nerek, cukrzyca, powikłania pochorobowe, np. po śwince, odrze, zapalenie ucha środkowego, wewnętrznego, przyjmowanie leków ototoksycznych, zapalenie opon mózgowo-rdzeniowych. W późniejszym okresie życia są to: choroby układu kostnego, nerek, cukrzyca, hałas, procesy degeneracyjne organizmu.

Podaję dla przykładu ustalenia dokonane przez K. Plutecką [2010, s. 58-59] w zakresie przyczyn występowania głuchoty wśród 39 wychowanków Specjalnego Ośrodka Szkolno-Wychowawczego w Krakowie. Sześciu uczniów (15\%) posiadało uwarunkowania genetyczne, 10 (26\%) nabyło wadę słuchu w okresie płodowym, 9 (23\%) w okresie okołoporodowym, 8 (21\%) we wczesnym dzieciństwie i u 6 (15\%) uczniów nie udało się określić przyczyny takiego stanu zdrowia. Na szczególną uwagę zasługuje fakt, iż w grupie badanych dzieci najczęściej głuchocie towarzyszyły różnorodne dysfunkcje rozwojowe, np. niepełnosprawność intelektualna w stopniu lekkim, wady wzroku, zaburzenia równowagi, zaburzenia neurologiczne, niepełnosprawność intelektualna w stopniu umiarkowanym, ADHD itp., a u 4 uczniów (10\%) występowało więcej niż jedno dodatkowe zaburzenie.

W sytuacji fundamentalnego znaczenia analizatora słuchowego dla prawidłowego rozwoju poznawczo-społeczno-osobowościowego, satysfakcji i szeroko pojętego dobrostanu oraz ryzyka uszkodzenia słuchu we wszystkich etapach życia, zasadne jest przeprowadzanie przesiewowych badań słuchu. Dla dzieci w okresie noworodkowym i niemowlęcym systematycznie dokonuje się to od kilkunastu lat, za sprawą Fundacji Wielkiej Orkiestry Świątecznej Pomocy. Dlatego już od pierwszych dni życia dziecka potencjalne jest wykrycie podejrzenia uszkodzenia słuchu. Dzięki temu można szybciej, bardziej trafnie i skutecznie planować oraz realizować rehabilitację. Procedura postępowania screeningu słuchowego jest następująca. Jeśli pierwsze badanie słuchu wykaże aberrację, wówczas powinno się je powtórzyć w dniu wypisu ze szpitala. Dzieci z nieprawidłowym wynikiem oraz z grupy ryzyka otrzymują w książeczce zdrowia ostrzegawczą żółtą naklejkę i zostają skierowane do specjalistycznych ośrodków celem kontynuowania diagnostyki. Jednakże od zaangażowania rodziców i lekarza rodzinnego zależy 
realizacja wytyczonej drogi działania, gdyż nie ma wypracowanego systemu kontroli wykonania zaleceń. Zdarza się, że ponowne badania słuchu zostają zrealizowane dopiero wówczas, gdy pojawią się społecznie widoczne objawy utraty słuchu [Radziwanowska-Krajewska 2016, s. 18]. Tak więc praktyka pokazuje, że wyposażenie ośrodków $\mathrm{w}$ wysokospecjalistyczne urządzenia do rozpoznawania uszkodzeń słuchu oraz stworzenie mechanizmu, programu wczesnej diagnostyki i rehabilitacji, nie chroni przed błędami, u podstaw których leży niefrasobliwość jej uczestników.

Inny problem w zakresie diagnostyki słuchu obserwuje się w sytuacji osób starszych. Badanie TNS 2014 (P 7, P 8, P 8a) wskazało, że połowa lekarzy pierwszego kontaktu, jak i lekarze laryngolodzy nie pytają swoich pacjentów o ewentualne problemy ze słuchem. Jednak, gdy to nastąpi i potwierdzi się obawa o pogorszenie słuchu, wówczas tylko w połowie przypadków lekarze rodzinni kierują na dalsze specjalistyczne rozpoznanie (P 13). Badania TNS z 2014 r. potwierdzają wiedzę powszechną o trudnościach $\mathrm{w}$ diagnozowaniu, leczeniu, a potem protezowaniu słuchu i rehabilitacji.

Jeśli osoby odpowiedzialne za diagnozę słuchu i wyznaczanie dalszej drogi postępowania nie są uwrażliwione na problem, to przy występującym nieuzasadnionym zawstydzeniu osób z wadą słuchu (badania TNS 2014, P 17) trudnością jest skuteczne przeciwdziałanie negatywnym skutkom deprywacji słuchowej, jakimi są m.in. zmniejszenie satysfakcji życiowej i kontaktów społecznych.

\section{Stan słuchu dzieci i osób starszych w świetle badań}

„Zgodnie z danymi epidemiologicznymi Światowej Organizacji Zdrowia uszkodzenie słuchu istotnie ograniczające sprawność słuchową występuje u 5\%, czyli około $360 \mathrm{mln}$ ludzi na świecie [www.who.int]. Uważa się przy tym, że istotne ograniczenie sprawności słuchowej występuje wtedy, gdy średni niedosłuch w częstotliwościach mowy przekracza $40 \mathrm{~dB}$ HL u dorosłych i $30 \mathrm{~dB}$ HL u dzieci (w uchu lepiej słyszącym). Jeśli weźmiemy pod uwagę również niedosłuchy niewielkiego stopnia, nieupośledzające istotnie wydolności społecznej, odsetek ten w ogólnej populacji wynosi 12-17\%" [Biuletyn PSPS. Wydanie Specjalne 2017, s. 18]. Utrata słuchu z przyczyn biologicznych rozpoczyna się od około 30 r.ż., ze szczególnym nasileniem po 65 r.ż. [Pruszewicz 2003, s. 64].

„Opracowania statystyczne wielu ośrodków klinicznych wskazują na stały wzrost liczby ludności będącej w wieku ponad 60 lat, która w 2005 r. ma osiągnąć liczbę 1,1 miliarda (1/6 populacji). Upośledzenie słuchu w tej grupie ludności jest najbardziej rozpowszechnione i stanowi bardzo ważny problem społeczny" [Pru- 
szewicz 2003, s. 403]. „Odsetek ludzi z głuchotą starczą obejmujący populację w wieku 65-75 lat oblicza się od 6\% do 10\% [Pruszewicz 2003, s. 404]. Według Światowej Organizacji Zdrowia uszkodzenie słuchu na poziomie zasadniczo ograniczającym sprawność słuchową występuje u 5\% ludności świata (360 mln) [za: Śliwińska-Kowalska 2017, s. 18]. W sytuacji gdy uwzględni się niewielkiego stopnia problemy w słyszeniu, to wskaźnik ten wzrośnie do 12-17\% ogółu ludności. W Polsce na koniec 2014 r. według danych GUS [2014, s. 113-115] było prawie 4,7 mln osób z niepełnosprawnością powyżej 15 roku życia. Wśród niepełnosprawnych dorosłych $19 \%$ posiadało dysfunkcję słuchu.

Celem zilustrowania problemu posłużę się danymi uzyskanymi w Lubuskim Urzędzie Wojewódzkim w Gorzowie Wielkopolskim.

Analiza liczby orzeczeń o niepełnosprawności wydanych przez Wojewódzki Zespół ds. Orzekania o Niepełnosprawności w Gorzowie Wielkopolskim w latach 2012-2016 (rys. 1) pokazuje, że po 40 r.ż. i 60. roku życia następuje dynamiczny przyrost niepełnosprawności słuchowej.

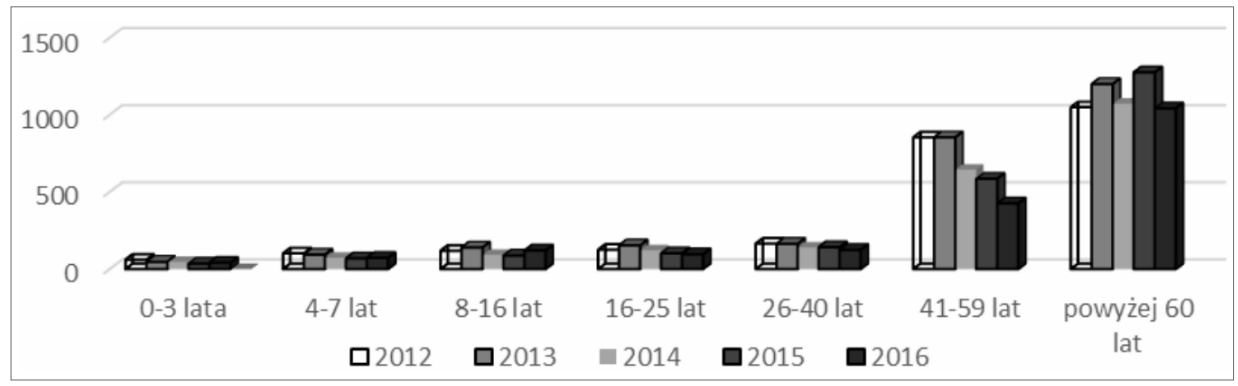

Rysunek 1. Liczba orzeczeń o niepełnosprawności z kodem 03-L wydana przez Wojewódzki Zespół ds. orzekania o Niepełnosprawności w Gorzowie Wielkopolskim w latach 2012-2016 Źródło: Lubuski Urząd Wojewódzki.

Na podstawie danych GUS [2009, s. 72] stwierdza się, że: „Częstość występowania niepełnosprawności rośnie wraz z wiekiem, gwałtownie po ukończeniu 40 roku życia. Wśród czterdziestolatków niepełnosprawna jest co dziesiąta osoba, a wśród pięćdziesięciolatków - blisko co piąta, natomiast w grupie osób 70-letnich i starszych prawie co druga". Ubytek słuchu dotyczy 14 \% osób posiadających orzeczenie o stopniu niepełnosprawności [GUS 2009, s. 74]

Kolejnymi okresami nasilonych problemów ze słuchem jest koniec okresu przedszkolnego i początek edukacji wczesnoszkolnej. Rysunek 2 dobitniej obrazuje istniejący stan rzeczy.

Rozkład danych statystycznych pokazany na rysunku 2 wskazuje, że wśród dzieci w wieku 4-7 lat obserwuje się częściej występowanie wad słuchu w porównaniu 
z młodszą grupą wiekową. Uważam, że proces ten jest spowodowany zarówno zwiększoną zachorowalnością dzieci, jak również bardziej trafnie przeprowadzoną diagnostyką słuchu. Dziecko przekraczając próg przedszkola zostaje włączone $\mathrm{w}$ wieloaspektowe działania społeczno-wychowawczo-poznawcze. Stawia się mu konkretne wymagania, którym powinno sprostać na miarę wieku biologicznego. Jeśli nie będzie dysponowało odpowiednimi kompetencjami i nie poradzi sobie $\mathrm{z}$ działalnością $\mathrm{w}$ przedszkolu rozpoczyna się proces zindywidualizowanych działań, równolegle z szeroko zakrojonymi aktywnościami diagnostycznymi. Opisany tok postępowania skutkuje zwiększoną wykrywalnością dysfunkcji lub nieharmonijności rozwojowych. Taka sama sytuacja zachodzi również w szkołach podstawowych. Analiza orzeczeń przyznanych przez Wojewódzki Zespół ds. Orzekania o Niepełnosprawności w Gorzowie Wielkopolskim (rys. 1) oraz poradnie psychologiczno-pedagogiczne (rys. 2) wskazuje, że krytycznymi okresami istotnymi w diagnostyce słuchu są czasy przedszkola, szkoły podstawowej i gimnazjum, a następnie średni i starszy wiek życia.

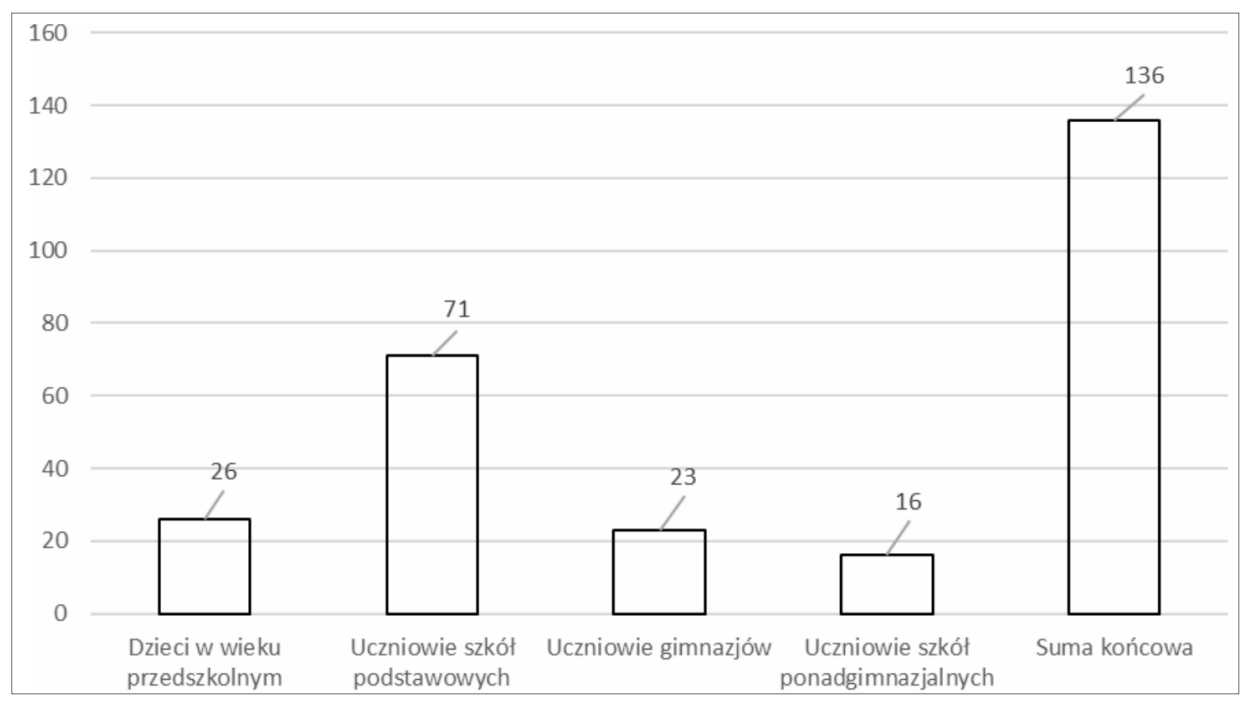

Rysunek 2. Liczba wydanych orzeczeń przez poradnie psychologiczno-pedagogiczne niesłyszący/słabosłyszący od 1.01.2016 do 30.09.2016 w województwie lubuskim Źródło: Kuratorium Oświaty w Gorzowie Wielkopolskim.

W badaniach przesiewowych w roku szkolnym 2015/2016 [www.sponin. org.pl] uzyskane dane ankietowe wykazały, że u prawie 13\% badanych uczniów wystąpiło podejrzenie utraty słuchu, $\mathrm{w}$ tym $\mathrm{u}$ ponad $30 \%$ niedosłuchu obustronnego. W gminach wiejskich prawie $80 \%$ rodziców dzieci z trudnościami w słyszeniu nie zauważają tego problemu. Taką sytuację potwierdziły również badania 
J. Szostak [2016, s. 29-32] przeprowadzone pod kierunkiem A. Lis-Zaldivar na grupie rodziców 37 uczniów gimnazjum. Badani rodzice bagatelizowali katary, przeziębienia dzieci, jak i inne choroby, które mogą przyczynić się chociażby czasowo do obniżenia ostrości słuchu. Uważają jednak za zasadne wykonywanie przesiewowych badań słuchu celem wczesnego wykrywania wad. Wyniki badań J. Szostak [2016] wykazały, że żaden gimnazjalista nie dysponował wzorcowym słuchem, a 18 na 37 badanych miała lekkie obniżenie słuchu w zakresie niskich tonów i 8 na 37 w zakresie wysokich tonów. Ponadto stwierdzono, że młodzież wykazała się niższą wrażliwością na hałas, co w przyszłości może skutkować obniżeniem ostrości słyszenia. Rezultaty badań przesiewowych przeprowadzonych wśród siedmioletnich dzieci w latach 2008-2013 zobrazowano syntetycznie na rysunku 3.

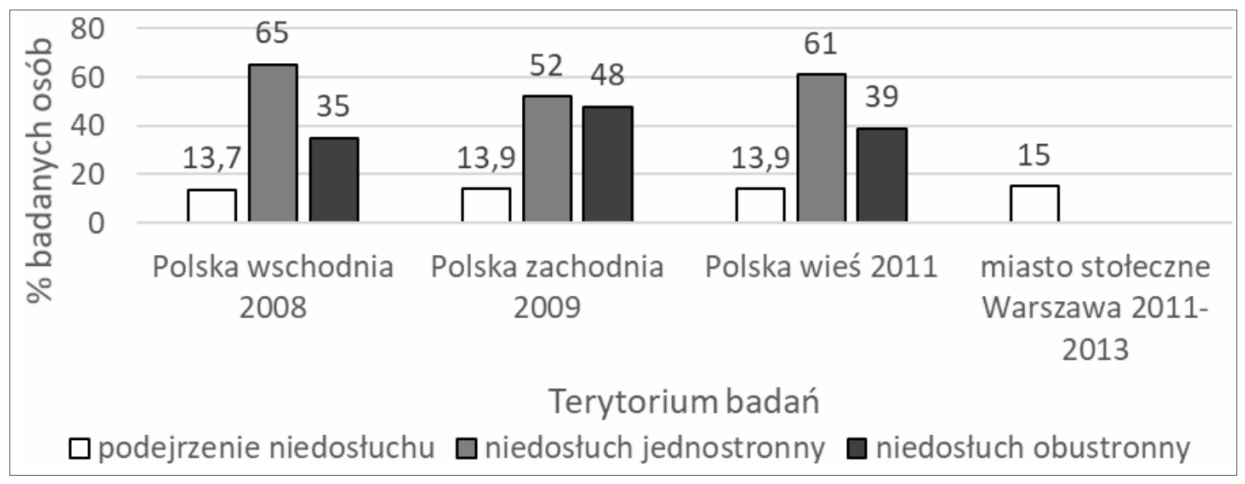

Rysunek 3. Wyniki przesiewowych badań słuchu przeprowadzonych wśród 7-letnich uczniów i starszych w latach 2008-2013

Źródło: [Żukowicka 2014, s. 9-10].

Na ich podstawie można wysunąć wniosek, jak ważne jest kontynuowanie przesiewowych badań słuchu również i w tym okresie życia (nie poprzestając na noworodkowym). Jednostronne problemy w słyszeniu trudno jest zdiagnozować funkcjonalnie, gdyż następuje kompensacja zdrowego ucha, a nieleczona choroba może przekształcić się $\mathrm{w}$ stały stan niedosłuchu, w wadę słuchu. W Polsce według danych GUS [2009, s. 265, 273] prawie 7 tysięcy dzieci korzystało z aparatu słuchowego w wieku od o do 4 lat, 9,2 tysiące w wieku 5-9 lat.

Narodowy Test Słuchu przeprowadzany przez firmy Siemens, Audio Service we współpracy z firmami protetyki słuchu w 2015 r. [Biuletyn PSPS, 4/2015, s. 14] pokazał nowe, niepokojące zjawisko. Obejmował prawie 50 tys. mieszkańców z różnych rejonów Polski (łącznie 150 miejsc). Zgodnie z procedurą był wykonywany dwu etapowo. Wszyscy uczestnicy przechodzili test stricte przesiewowy 
ecola, trwający 1 minutę. Jeśli wykazano jakikolwiek problem, wykonywano dokładne audiometryczne badanie słuchu. Rezultaty badań reprezentuje rysunek 4 .

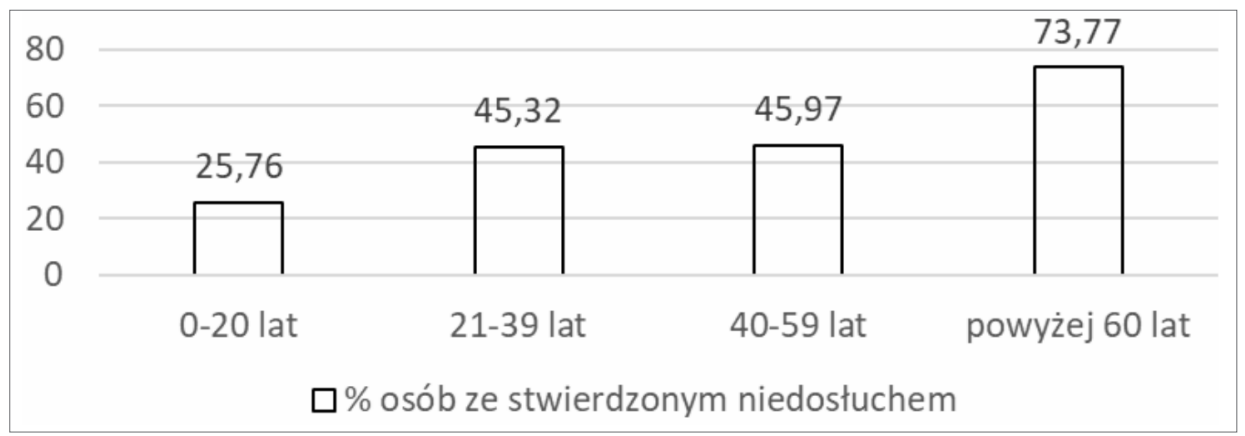

Rysunek 4. Wyniki Narodowego Testu Słuchu w latach 2011-2015 przeprowadzonego w Polsce przez firmę Siemens/Audio Service

Źródło: Biuletyn PSPS, 4/15, s. 14.

Analiza danych uzyskanych w Narodowym Teście Słuchu jednoznacznie wykazała, że liczba osób w wieku 21-39 lat ze zdiagnozowanym problemem w słyszeniu jest taka sama, jak u 40-59-latków. Tak więc osoby młodsze o około 20 lat dysponują taką samą ostrością słuchu, jak starsi uczestnicy screeningu. Jest to nowa osobliwość w zakresie uszkodzeń słuchu, którą w kolejnych edycjach ogólnopolskich badań należy potwierdzić lub odrzucić.

Komisja Europejska [za: Śliwińska-Kowalska 2017, s. 18-19] zwróciła uwagę na implikację stosowania osobistych odtwarzaczy muzyki z ryzykiem uszkodzenia słuchu. Być może wcześniej przytoczone dane Narodowego Testu Słuchu są tego potwierdzeniem.

Klasyfikacja ubytków słuchu i jakość słyszenia osób niedosłyszących

Tak jak powszechnie wiadomo, na poziom słyszenia przy występującym niedosłuchu wpływa nie tylko czas pojawienia się problemu, ale również stopień ubytku słuchu. Wyróżniamy kilka klasyfikacji. Według kryteriów ANSI i ISO [za: Pruszewicz 2003, s. 340] od $0 \mathrm{~dB}$ do $20 \mathrm{~dB}$, jest norma słyszenia, od $21 \mathrm{~dB}$ do $40 \mathrm{~dB}$ jest niedosłuch stopnia lekkiego, od $41 \mathrm{~dB}$ do $60 \mathrm{~dB}$ jest niedosłuch średni, od $61 \mathrm{~dB}$ do $80 \mathrm{~dB}$ jest niedosłuch głęboki i powyżej $81 \mathrm{~dB}$ głuchota. Zgodnie z ANSI i ISO istnieje również odrębny podział utraty słuchu [za: Pruszewicz 2003, s. 340]: $10-20 \mathrm{~dB}$ słuch w granicach normy, od 21-40 dB niewielki ubytek, $41-55 \mathrm{~dB}$ umiar- 
kowany ubytek, 56-70 dB umiarkowany/nasilony ubytek słuchu, 71-90 dB nasilony ubytek, powyżej $91 \mathrm{~dB}$ - głęboki ubytek. Międzynarodowe Biuro Audiofonologii podaje nieznacznie odmienną typologię: od 20-40 dB lekki ubytek słuchu, od 40-70 dB umiarkowany ubytek słuchu, od 70-90 dB znaczny, powyżej $90 \mathrm{~dB}$ gęboki ubytek słuchu 9 [Sękowska 1998, s. 167]. Biorąc pod uwagę DSM-5 zaburzenia mowy spowodowane utratą słuchu można zakwalifikować do grupy 3.1.2, jako zaburzenia językowe, zaburzenia tworzenia dźwięków mowy [First M.B, M.D 2016, s. 36]. Występuje również funkcjonalna normalizacja deficytu słuchu. C.Rojskjaer [Sękowska 1998, s. 168] wyróżnił niedosłuch lekki, kiedy dzieci pomimo niedosłuchu nie korzystając $\mathrm{z}$ aparatów słuchowych mogą pobierać naukę w szkołach masowych. Średni niedosłuch, kiedy wymagane jest już stosowanie aparatów słuchowych, jednakże dzieci nadal uczęszczają do szkół masowych. Osoby posiadające już wyraźne wady wymowy wymagające specjalistycznych ćwiczeń logopedycznych wówczas zakwalifikowane są do grupy z poważnymi niedosłuchami. W grupie z głębokim niedosłuchem wyróżnia się dwie podgrupy: dzieci, które odnoszą korzyści z korzystania z aparatów słuchowych, oraz te, dla których nie są one skuteczne w rehabilitacji słuchu i mowy. Według Rozporządzenia MEN z 1993 wyróżniamy dzieci słabosłyszące, które słyszą i rozumieją mowę, pomimo występujących u nich wad słuchu oraz dzieci niesłyszące, które tylko dzięki aparatom słuchowym odbierają dźwięki mowy lub nawet po zastosowaniu protez słuchu nie rozumieją mowy ustnej. $Z$ punktu widzenia działań praktycznych klasyfikacja funkcjonalna daje pełniejszy obraz skutków deficytów słuchu, zarówno w odniesieniu do dzieci, jak również osób dorosłych.

Czas postania niedosłuchu wiąże się z odmiennymi problemami. Jeśli rozpoczął się w średnim bądź starszym wieku przenika w szczególny sposób na relacje społeczne i komunikację werbalną. Zmienia sytuację zawodową i obniża poczucie bezpieczeństwa społeczno- środowiskowego. Kiedy zaburzenia słuchu datują się we wczesnym okresie rozwojowym dziecka, wpływają również na szeroko pojętą komunikację społeczną oraz na sferę poznawczą, w tym egzystencjonalną, pozycję w grupie rówieśniczej, bezpieczeństwo.

Badania EuroTrak Polska [Biuletyn PSPS, II/2017, s. 6], których celem było zweryfikowanie satysfakcji osób noszących aparaty słuchowe wyjawiło, że około $16 \%$ badanych (z 40 tys.), to osoby z ubytkami słuchu, $1 / 3$ z nich korzysta z aparatów słuchowych. Dane GUS [2009] pokazują, że 3\% populacji osób dorosłych w Polsce używa aparatu słuchowego. Są to przeważnie osoby po 70-tym roku życia. 96\% osób ankietowanych w Euro Trak twierdzi, że dzięki aparatom słuchowym ogólnie poprawiła się jakość ich życia. Dane GUS [2009] wskazują jednak, że co szósty sześćdziesięciolatek i co drugi siedemdziesięciolatek ma problem ze zrozumieniem mowy, gdy rozmawia z kilkoma osobami. Jest to bardzo trudna do zlikwidowania komplikacja, gdyż rozpoznawanie i różnicowanie dźwięków nie zależy 
tylko od poziomu głośności, ale w dużej mierze od ogólnej sprawności poznawczej i neurobiologicznej osób. A z tym osoby starsze mają problem. Dane uzyskane w badaniach TNS nt. słuchu seniorów w 2014r (P6a), wskazują, że co czwarta osoba z ubytkiem słuchu rezygnuje z rozmowy w głośnym otoczeniu, co piąta z rozmowy telefonicznej, oglądania telewizji i prawie co piąta ze spotkań towarzyskich z rodziną, bądź znajomymi. Prawie co trzecia osoba ze zdiagnozowanym niedosłuchem uważa, że można wstydzić się swojej dolegliwości i można ukrywać ją przed osobami bliskimi (P17). I równie tyle samo miało do czynienia z nieprzyjemną reakcją osób w swoim otoczeniu, gdy czegoś osoba niedosłysząca nie usłyszała (P19). Według mnie jest to sytuacja o tyle niepokojąca, że te poglądy i zdarzenia przeważnie ( wnioskuję na podstawie danych GUS) dotyczą osób starszych, które z racji wieku i doświadczenia powinny być szanowane i poważane $\mathrm{w}$ społeczeństwie, a nie mają takiego odczucia. $\mathrm{Z}$ drugiej strony są to rodzice, dziadkowie, którzy nie akceptują swojej przypadłości. Na tej podstawie wnioskuję, że w sytuacji diagnozy problemów dziecka bądź wnuka ze słyszeniem nie będą akceptować zaistniałego stanu. Jest też prawdopodobne, że decyzjami mogą opóźniać leczenie, protezowanie słuchu bądź rehabilitację.

\section{Zakończenie}

Słuch jako jeden z głównych zmysłów poznania świata powinien być szczególnie chroniony. A troska o prawidłowość jego funkcjonowania obiektem zainteresowania każdego człowieka. Tymczasem wyniki przytoczonych badań pokazują, że lekarze i rodzice nie przywiązują wagi do kontrolowania jego sprawności. Wyjątkiem jest okres tuż po urodzeniu dziecka, kiedy to przeprowadza się powszechne przesiewowe badania noworodków. Niestety brak świadomości rodziców znaczenia słuchu w rozwoju dziecka lub ich niefrasobliwość skutkuje podjęciem rehabilitacji dopiero wówczas, gdy skutki deprywacji słuchowej są funkcjonalnie zauważalne. Po 65 r.ż. następuje intensywny wzrost liczby osób o obniżonym słuchu. Jednakże problem utraty słuchu według opinii seniorów jest wstydliwy i część osób preferuje ukrywanie go niż podjęcie leczenia bądź protezowania słuchu. Te osoby, które zdecydowały się na noszenie aparatów słuchowych w większości sytuacji życiowych uzyskały poprawę jakości życia i komfort.

\section{Literatura}

Aparaty stuchowe moga znaczaco poprawić jakość życia - wywiad z prof. dr hab. Mariola Śliwińskq-Kowalska (2017), Biuletyn PSPS, Wydanie Specjalne, Zarząd Polskiego Stowarzyszenia Protetyków Słuchu, Zielona Góra. 
Eliot L. (2003), Co tam się dzieje? Jak rozwija się mózg i umysł w pierwszych pięciu latach życia, Media Rodzina, Poznań.

First M.B., M.D. (2016), DSM-5. Diagnostyka różnicowa, Edra Urban \& Partner, Wrocław.

Korniszewski L (2015), Jakie geny odpowiadaja za niedostuch?, „Słyszę” 5/133, http://slysze. ifps.org.pl/w-numerze-51332013-wrzesienpazdziernik/.

Piaget J., Inhelder B. (1966), Psychologia dziecka, Siedmiogród, Wrocław.

Plutecka K. (2010), Komunikacja pozawerbalna niestyszacych uczniów z dodatkowymi dysfunkcjami rozwojowymi, „Niepełnosprawność”, $\mathrm{nr} 4$.

Radziwanowska-Krajewska A. (2016), Wptyw świadomości rodzica na przebieg rehabilitacji dziecka z niedostuchem, niepublikowana praca końcowa studiów podyplomowych z logopedii, w zbiorach Akademii im. Jakuba z Paradyża, Gorzów Wielkopolski.

Pruszewicz A. (red.) (2003) Audiologia kliniczna. Zarys, Wydawnictwo Akademii Medycznej im. K. Marcinkowskiego w Poznaniu, Poznań.

Sękowska Z. (1998), Wprowadzenie do pedagogiki specjalnej, WSPS, Warszawa.

Szostak J. (2016), Ocena stanu stuchu uczniów gimnazjum w Bledzewie w roku szkolnym 2015/2016, niepublikowana praca końcowa studiów podyplomowych z logopedii, w zbiorach Akademii im. Jakuba z Paradyża, Gorzów Wielkopolski.

Wady wrodzone. Jak geny wptywaja na nasz stuch (2016), Audiology News. Medyczny biuletyn informacyjny, Siemens AG/Signia, 04.

Żukowicka E. (2014), Przesiewowe badania stuchu jako możliwość wyrównywania szans edukacyjnych u dzieci z niedostuchem w wieku szkolnym, http://2014_2_9_147_ewaukowicka.

Strony internetowe:

http://slysze.inz.waw.pl/w-numerze-51332013-wrzesienpazdziernik/ www.sponin.org.pl. https://stat.gov.pl/obszary-tematyczne/zdrowie/zdrowie/stan-zdrowia-ludnosci-polski-w-2014-r-,6,6.html.

https://stat.gov.pl/obszary-tematyczne/ludnosc/ludnosc/ludnosc-i-ruch-naturalny-w-2016-r-,30,1.html.

http://docplayer.pl/6456107-Sluch-polskich-seniorow-2014-wyniki-badania-tns-polska.html.

www.who.int/healthinfo/statistics/bod hearingloss.pdf.

https://stat.gov.pl/cps/rde/xbcr/gus/ZO_stan_zdrowia_2009.pdf. 